\title{
Detection of Salmonella enterica in Synanthropic Birds in the Metropolitan Area of Goiania-Go
}

Hilari W Hidasi ${ }^{1 *}$, Maria Auxiliadora Andrade ${ }^{1}$, Guido FC Linhares ${ }^{1}$, Valéria de Sá Jayme ${ }^{1}$, Denizard AA Delfino ${ }^{1}$ and Derek A Rosenfield ${ }^{2}$

${ }^{1}$ Goiás Federal University, Brazil

${ }^{2}$ São Paulo University, Brazil

*Corresponding author: Hilari W Hidasi, Goiás Federal University, Brazil, Tel: +5511995508189; E-mail: hhidasi@yahoo.com.br

Received date: November 07, 2014; Accepted date: May 28, 2015; Published date: June 04, 2015

Copyright: @ 2015 Hidasi HW, et al. This is an open-access article distributed under the terms of the Creative Commons Attribution License, which permits unrestricted use, distribution, and reproduction in any medium, provided the original author and source are credited.

\begin{abstract}
Free living birds are considered a potential source of pathogens for livestock. In order to assess their importance in the epidemiological chain of avian salmonellosis, 260 biological samples were taken from two species with known synanthropic behavior: (a) Pigeon (Columbia livia) and (b) Black-headed vulture (Coragyps atratus). Both were screened for the presence of Salmonella enterica, with subsequent serotyping of positive samples. To facilitate the above mentioned serotyping of the biological samples we adopted conventional bacteriological methods and rPCR analysis. During the bacteriological examination a total of $13 \%(26 / 200)$ samples from the pigeons, were found positive. Of those isolated, 73\% (19/26) were identified as Salmonella enterica, serotype Schwazengrund; $23.07 \%$ was identified as Salmonella enterica, serotype Typhimurium, 3.84\% (1/26) was identified as Salmonella enterica, serotype Enteriditis. The results of the rPCR analysis showed $27 \%(54 / 200)$ as being positive with Salmonella enterica. None of the 60 samples taken from the vultures, showed up as positive during the conventional bacteriological exams, contrarily to the rPCR analysis, which detected $8.3 \%(5 / 60)$ as positive. In conclusion, pigeons and black-headed vulture from the metropolitan area of Goiânia could be identified as carriers of Salmonella species.
\end{abstract}

Keywords: Bacteriology; Pigeons; Salmonellosis; rPCR; Vultures

\section{Introduction}

The Brazilian poultry production has been responsible for much of the economic gains of the country. The country now ranks third as a producer of broiler chickens and is the largest exporter, supplying to 142 countries [1]. The animal's well-being is essential to guarantee a good final product and, therefore, biosecurity measures are considered crucial the overall sanitary control within the poultry industry. One such measure recommends avoiding contact with free-living birds, in order to circumvent the transmission of pathologic agents, as they are considered potential disease carriers [2].

In search for food and shelter, free-living synanthropic birds seek out areas of close to human habitats and domesticated animal farms, and by doing so, may contaminate them with alien livestock pathogens [3]. Among them are the in the Brazil widely distributed common pigeon (Columba livia), and also the black-headed vulture, or the common buzzard (Atratus atratus) [4-6], a bird species that feeds on carcasses and other decaying organic materials, including human waste, which is considered an important contributor to the spread of Salmonella and other pathogens between humans and animals [7].

In order to ensure the quality of poultry products available for foreign and domestic markets, the Ministry of Agriculture, Livestock and Supply (MAPA) introduced the National Poultry Health Program (NPFS; Ministerial Decree No. 193, September the $\left.19^{\text {th }}, 1994\right)$. Among other measures, the program seeks to monitor and to grant credentials to farms "free" of Salmonella enterica, serotype Gallinarum and Salmonella enterica, serovar Pullorum; and "free" or "under control" for Salmonella enterica, serotype Enteritidis and Typhimurium [8].
It seems apparent that there is a correlation between the spread of Salmonella in free-living birds and environmental contamination. The inadequate treatment of sewage or manure, associated with large flocks of birds interacting with contaminated surroundings, favoring crosscontamination and, consequently, the spread of Salmonella throughout the environment. This in turn increases the probability of other wild animals to be exposed to infectious agents, which become intestinal carriers, contributing to the dispersion of this bacterium [9]. As a result, free-living birds have been the subject of several studies in many countries with the focus on transmission dynamics of zoonotic pathogens between potential wildlife disease-carriers and livestock production, with the objective to providing safe foods, as these pathogenic agents are known to provoke frequently severe toxicoinfections in humans [10].

Besides the importance of being potential reservoir hosts for Salmonella, which can readily be transmitted to poultry production and humans, furthermore, the introduction of this pathogenic agent into the population of free-living species may prove to be a major ecological problem, in so far that the disease can be fatal to some wildlife species [11-13].

Considering the shortage of studies of this disease in synanthropic birds and their potential role as unsuspected carriers, this study was conducted in order to corroborate the presence of Salmonella in freeliving birds, using the techniques of conventional bacteriology, rPCR, and serotyping of isolated biological samples from the common pigeons and black-headed vultures, captured in close proximity to commercial poultry farms in the metropolitan region of Goiânia-GO. 


\section{Materials and Methods}

\section{Local}

The experiment was conducted at the experimental center of poultry diseases at the laboratories for bacteriology and molecular biology, department of veterinary medicine, college of veterinary and animal science (EVZ) at the Federal University of Goiás (UFG) and the Wildlife Center of Goiás (CETAS/GO).

\section{Animals and sample collection}

200 pigeons (Columbia livia) and 60 black-headed vultures (Atratus atratus) were tested.

The pigeons were captured over a year at random, in the Goiânian metropolitan region, at a radius of $50 \mathrm{~km}$ of poultry farms.

To capture, five traps of galvanized steel, $1.00 \mathrm{~m}^{3}$, model argentina (hebei panfa trade co, ltd), were used. These traps were placed in the morning and remained open throughout the day. Inspection was done sporadically during the day to remove captured birds. Caught pigeons were removed from the traps; placed in carrying cages, and transported to the laboratory of the experimental center for bird diseases. Next they were euthanized and samples of intestinal contents were collected.

The vultures used in this experiment were captured by environmental authorities and delivered to the wildlife center (CETAS-GO). Once received, the birds were contained and manual swaps from the vent (cloaca) were taken. The samples were packed in insulated Styrofoam boxes containing ice and transported immediately to the laboratory for bacteriological analyzes.

This study was conducted with a permit obtained from the Brazilian institute of environment and renewable natural resources-IBAMA; instituto chico mendes of biodiversity conservation-ICMBio; authorization and biodiversity information system - SISBIO, protocol nr. 25795-1, and approved by the ethics committee on animal experimentation of the federal university of Goiás, protocol nr. 080/11.

\section{Conventional bacteriology}

For the isolation and identification of Salmonella species the samples were subjected to conventional bacteriological analysis, according to Georgia Poultry Laboratory (1997) [14].

About 2 grams of feces, or cloacal swabs were inoculated in peptone water solution of $0.1 \%$ and incubated at $37^{\circ} \mathrm{C}$, for $18 \mathrm{hrs}$. Then $0.1 \mathrm{ml}$ of this solution was transferred to two tubes, each containing rappaport vassilidis solution or, alternatively, $1 \mathrm{ml}$ of selenite broth, which were than incubated at $37^{\circ} \mathrm{C}$, for $12-24 \mathrm{hrs}$. After the selective enrichment broth was placed in three cell-culture dishes with three different culture media: XLT4 (Difco), brilliant green agar (Difco), and hecktoen agar (Difco) agar, and all plates were incubated at $37^{\circ} \mathrm{C}$ for $18 \mathrm{hrs}$. From each dish, three colony-forming units presenting a morphology suggestive to belonging to the genus Salmonella, were inoculated in tubes containing agar TSI (triple sugar iron), (Difco), and incubated at $37^{\circ} \mathrm{C}$, for $18 \mathrm{hrs}$. The TSI tubes which presented similar morphologic features and suggestive of Salmonella were selected and then subjected to urease production tests, indole proof, the $\mathrm{H}_{2} \mathrm{~S}$, methyl red test, motility test, Simmons citrate, malonate, and the lysine decarboxylase test. The samples that reacted "positive" during the biochemical tests were sent to the fiocruz laboratory (Rio de Janeiro), where they were serotyped.

Aliquot parts of the selenite broth of all samples were frozen at $-20^{\circ} \mathrm{C}$ and later processed by real-time PCR (rPCR).

\section{Technique of real time PCR}

Extraction of genomic DNA samples: Before the extraction procedure, the frozen selenite broth samples were subjected to a new bacterial enrichment and, subsequently, the DNA of the samples was extracted by applying a heat treatment method, according to SANTOS et al. [15]. Afterwards, the end product was cooled, aliquoted and stored at $-20^{\circ} \mathrm{C}$ for later use.

The assays product for the rPCR detection of Salmonella species. were performed according to Calvo et al. [16].

The eluates obtained from extracted samples were used to perform $\mathrm{rPCR}$, using the TaqMan system. The volume was set at $20 \mu \mathrm{l}$, using $4.6 \mu$ of water milli-Q, $10 \mu \mathrm{l}$ of Master mix (1x), $2 \mu \mathrm{l}$ of IPC mix (10x), $0.4 \mu \mathrm{l}$ of $50 \mathrm{x}$ IPC DNA, and $1 \mu \mathrm{l}$ of oligonucleotides primer mixture and a probe (the primer at a concentration of $30 \mathrm{mM}$ ), and adding $2 \mu \mathrm{l}$ of test sample DNA. As an internal control of the reaction, in one sample well, of the 96 wells microtiter plate, a IPC DNA with an IPC blocking reagent was used (negative control-blocked IPC, Life ${ }^{\circ}$ ) and one other well with IPC DNA without an blocking agent. Amplification was performed in a thermocycler StepOne Plus (Applied Biosystems) under the following conditions: pre PCR at $60^{\circ} \mathrm{C}$, for 30 seconds, followed by $95^{\circ} \mathrm{C}$, for 10 minutes, 40 cycles at $95^{\circ} \mathrm{C}$, for 15 seconds (denaturation), followed by $60^{\circ} \mathrm{C}$, for 1 minute and $60^{\circ} \mathrm{C}$, for 30 seconds, for extension.

For detection of Salmonella species the oligonucleotides primers SAL1410f 5'-GGTCTGCTGTACTCCACCTTCAG-3 ' and SAL1494r 5'-TTGGAGATCAGTACGCCGTTCT-3', and probe SAL1441pr FAM-TTACGACGATATTCGTCCGGGTGAAGTG-TAMRA were used, developed by Calvo et al [16].

The samples were considered positive in which the generated amplification curves exceeded the cut-off line, as observed in stepone software program, v2.1 (applied biosystems). The degree of trust established for this analysis was $95 \%$.

\section{Statistical Analysis}

To interpret the results, a frequency analysis of the data was performed. For the concordance study between the tests, a Kappa coefficient $(\kappa)$ was used, where the conventional interpretation range of $\kappa$ values were as follows: $0.00-0.20=$ poor concordance; from 0.21 to $0.40=$ fair; 0.41 to $0.60=$ moderate; 0.61 to $0.80=$ good; and $0.81-1.00=$ very good concordance. Negative values are interpreted as equivalent to 0.0 .

\section{Results}

During the conventional bacteriological examination of 200 fecal samples collected from domestic pigeons, 13\% (26/200) were positive for Salmonella species. Serotypes were identified by the fiocruz laboratory (RJ), of which $73.07 \%(19 / 26)$ were typed as Salmonella enterica serotype schwarzengrund, $23.07 \%(6 / 26)$ identified as Salmonella enterica serotype Typhimurium, and $3.84 \%(1 / 26)$ identified as Salmonella enterica serovar Enteritidis (Table 1). 
Page 3 of 6

\begin{tabular}{|c|c|c|}
\hline Serotype & N & Percentage \\
\hline Schwarzengrund & 19 & $73.07 \%$ \\
\hline Typhimurium & 6 & $23.07 \%$ \\
\hline Enteritidis & 1 & $3.86 \%$ \\
\hline Total & 26 & $100 \%$ \\
\hline
\end{tabular}

\begin{tabular}{|l|l|l|l|l|}
\hline Vulture & 0 & $60(100 \%)$ & $5(8.3 \%)$ & $55(91.7 \%)$ \\
\hline
\end{tabular}

Table 2: Results obtained in the two diagnostic tests to which the biological samples collected from pigeons and vultures were submitted.

In the concordance analysis between the two diagnostic methods, for the analysis of the samples obtained from the pigeons, the

Table 1: Frequency of Serotype Salmonella enterica: 13\% (26/200) of the fecal samples collected from domestic pigeons were identified as being positive (fiocruz laboratories, RJ). The samples were analyzed by conventional bacteriological examination.

rPCR analysis showed that $27 \%(54 / 200)$ of the samples collected from the common pigeons were positive for Salmonella sp.(Figure 1).

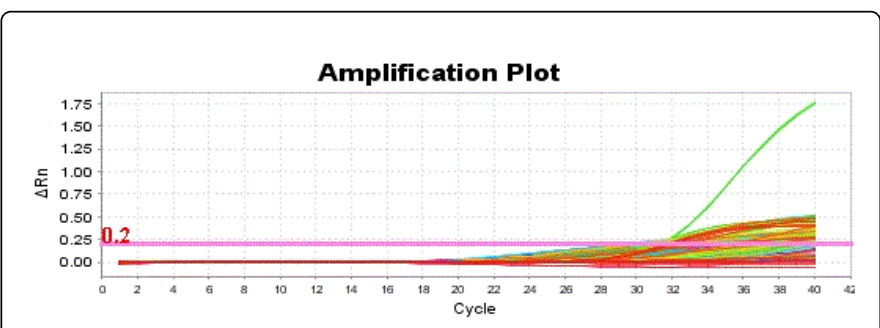

Figure 1: DNA amplification curves of the pigeon samples: (1) Threshold line; (2) positive curve for Salmonella species with 95\% confidence level; (3) negative curve for Salmonella species samples with a confidence level of $95 \%$.

All 26 of the pigeon derived samples showed to be positive with the conventional bacteriology method as well as with rPCR. Of the 60 samples taken from vultures, none was positive in the conventional bacteriological examination for the search agent. In the analysis of the same samples RPCR of vultures, $8.3 \%$ (5/60) Showed positive results (Figure 2).

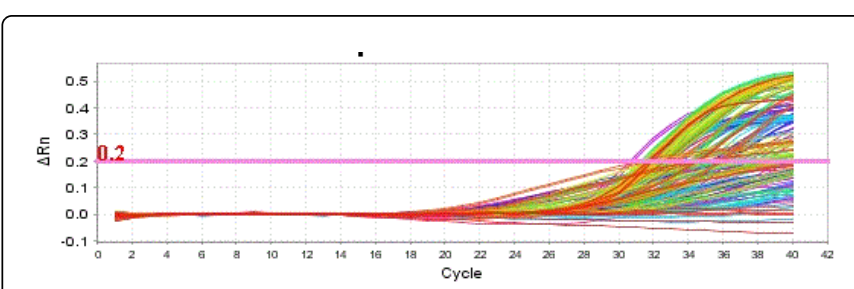

Figure 2: DNA amplification curves of the vulture samples: (1) Threshold line; (2) positive curve for Salmonella species with 95\% confidence level; (3) negative curve for Salmonella species samples with a confidence level of $95 \%$.

The results of the two laboratory tests are shown in Table 2.

\begin{tabular}{|c|c|c|c|c|}
\hline & \multicolumn{2}{|c|}{ Bacterial culture } & \multicolumn{2}{c|}{ rPCR } \\
\hline & Positive & Negative & Positive & Negative \\
\hline Pigeon & $26(13 \%)$ & $174(87 \%)$ & $54(27 \%)$ & $146(73 \%)$ \\
\hline
\end{tabular}

\begin{tabular}{|c|c|c|c|}
\hline & Kappa & Confidence Interval of 95\% & $\mathbf{p}$ \\
\hline \multirow{2}{*}{ Positive } & \multirow{2}{*}{0.576} & Superior $=0.701$ & \multirow{2}{*}{$<0.001$} \\
\cline { 3 - 3 } & & Inferior $=0.433$ & \\
\hline \multirow{2}{*}{ Negative } & \multirow{2}{*}{0.576} & Superior $=0.701$ & \multirow{2}{*}{$<0.001$} \\
\cline { 3 - 3 } & & Inferior=-0.433 & \multirow{2}{*}{$<0.001$} \\
\hline \multirow{2}{*}{ Geral } & \multirow{2}{*}{0.576} & Superior $=0.701$ & \\
\cline { 3 - 4 } & & Inferior: 0.45 & \\
\hline
\end{tabular}

Table 3: Values of the Kappa index, confidence intervals of $95 \%$ and $p$ values for the categories of 'positive' test 'negative', and the overall Kappa. Bacteriological culture and RPCR: categorical results of two tests were considered.

\section{Discussion}

In this study, a high frequency of Salmonella species were observed in common pigeons. The results obtained by rPCR analysis were $100 \%$ in consensus with the results obtain by bacterial culture.

The bacterial culture is the gold standard test for detecting Salmonella species in the animal feces, however, a period of approximately one week is necessary for the sample to be processed with this method. In comparison, the rPCR method allows a turnaround of the samples in a period of approximately 24 hours, including the time needed for bacterial enrichment. Molecular techniques have been used successfully in the detection of Salmonella, including analysis for specific serotypes [17]. Studies of contaminated foods by this pathogenic agent showed good results, with high concordance between PCR and bacteriological methods [18]. In the present study the technique of real-time PCR proved to be adequate and being an alternative when quick results are needed. As As a complementary method for detection of Salmonella sp., there were concurring to those reported by Temelli et al., and Sommer et al. $[19,20]$.

In both avian species analyzed in this study, positive results were more frequent by rPCR analysis, compared to the results obtained by conventional bacteriology methods. Negative results during the bacterial cultures can be correlated with a high number of uncultured or killed Salmonella cells, the number of cells in the sample, growth of other bacterial colonies in the culture [21], or even bacterial enrichment media used can be responsible for the decrease of sensitivity of the bacteriological technique, which may explain the higher positivity in molecular technique [22].

It was found that the serotypes identified in this research are of the species Salmonella enterica, which are not a specific serotype, thus, are not adapted to a single animal species. They can affect different species 
such as birds, fish and mammals. Free-living birds that live close to humans, due to increased levels of environmental contamination, are apparently more likely than other birds to become infected and remain intestinal carriers of this bacterium [17]. Depending on factors related to the bacterial serotype, host species, environmental conditions and degree of exposure of the animal to Salmonella, these infected animals may develop into asymptomatic hosts, or diseased by enteritis, acute septicemia, or chronic multifocal infection [9].

Similar research has been conducted by Akbarmehr [23] in Iran, where samples of ostriches, pigeons and broilers were investigated. In samples analyzed by bacteriological methods, the researcher noted a high occurrence of this pathogenic agent in pigeons, relative to the other species studied, that is, $15.5 \%$ of the birds were positive for Salmonella enterica, a result similar to that found in the present study, reinforcing the importance of this avian species in the epidemiology of salmonellosis.

The serotype most frequently found in fecal samples of common pigeons captured during this study was Salmonella enterica, serotype Schwarzengrund, a serotype little documented in Brazil. This pathogenic agent is responsible for human food poisoning and seems to have great importance in livestock production. In Asian countries this serotype was shown as one of the main contaminants of food products, including chicken, constituting a serious health problem in these countries [24,25]. Furthermore, Aarestrup et al. [26] reported that this serotype has little specificity as to the possibility of infecting animals and the possible spread of Salmonella enterica serotype Schwarzengrund in food for humans, reinforces its importance in public health.

Among the isolates of Salmonella species (23\%), six samples were identified as Salmonella enterica serotype Typhimurium. Detection of this serotype in pigeons have already been described in the literature by several authors. Pedersen et al. [27] conducted a study with pigeons captured in local dairy farms and also in urban centers. Only birds captured in the production areas were identified as positive for Salmonella enterica serotype Typhimuriume, $S$. enterica serovar Montevideo, with a total of $1 \%$ of 277 birds considered as positive. According to Doust and Prescott [9], there is a correlation between the prevalence of Salmonella in the intestinal tract of various species of wild birds and their proximity to people and livestock. These birds often take advantage of proximity to humans and domestic animals to find food and by doing so, contaminating it. This kind of exposure rarely involves clinical manifestations of the disease, and the elimination of bacteria in feces, in most cases, is short. Similarly, Marciano [28] detected Salmonella enterica, serovar Typhimurium in $8 \%$ of organs and feces of birds. Also Vucemilo et al. [29] performed a isolation of this serotype in a sample obtained from carrier pigeons, also of the species Columba livia, in Spain.

Researchers in Croatia isolated $S$. enterica, serotype Typhimurium in 17 of 107 samples examined in pigeons, getting a percentage rate of $15.3 \%$ positivity of this pathogenic agent, isolated from excrements by bacteriological examination [29].

In Belgium, Pasmans et al. [30] also conducted the isolation of this serotype in pigeons, with a frequency of $3.3 \%$ of birds considered positive, a result similar to that found here, with $3 \%(6 / 200)$ of positive samples for Salmonella enterica serotype Typhimurium. The results of this study indicate the pigeons as disseminators of Salmonella enterica serotype Typhimurium.
Of the samples where Salmonella species were isolated, one was identified as Salmonella enterica, serotype Enteritidis, which is in concordance with the results obtained in the study conducted by Sousa et al. [31], stating that biological samples from various species of wild birds were subjected to bacteriological and serological tests for the detection of Salmonella. Just as it has been detected in this study, Salmonella enterica serovar Enteritidis was isolated by conventional bacteriology from a sample of the species columbiforme.

Due to extensive contact with waste by domestic pigeons, these animals become more susceptible to infection by Salmonella, and turn into accidental hosts of this pathogenic agent $[32,33]$.

On the other hand, surveys conducted in Norway, using the same methods of conventional bacteriological analysis by collecting cloacal swabs, showed to be negative [34] The discrepancy between the results obtained in Norway and the present study could be explained by the characteristic excretion of Salmonella, which occurs intermittently. In addition, climatic conditions of that country as well as the lifestyle of the population, regarding the disposal of waste, may also have influenced the negative outcome, which are very distinct from the local conditions of the present study's area.

During bacteriological analysis of cloacal swabs of vultures, no sample was found to be positive for Salmonella enterica. Even tough, fewer samples have been analyzed, the results are in agreement with reports literature, that state that vultures have naturally a lower susceptibility to pathogens. In this regard, over the years many hypotheses have been advocated, considering the physicochemical and physiological conditions of the gastrointestinal tract of the animals, the evolutionary property of a specific absorption of this system, or the hypothesis of a more complex microflora throughout the digestive system. Hence, it is postulated that there is a microbe in the gastrointestinal system of these birds that compete with pathogenic agents, thus, reducing the risk of a disease spread [35-37]. This thought may be justified because none of the samples were positive during the conventional bacteriological examination and five of them were positive by rPCR. The positivity of the rPCR analysis is mostlikely explained by the high sensitivity of the technique, since this method is able to detect microorganism, even if with minimal amounts [18]. Also, it is possible that the organism has not been able to reproduce in the intestines of these birds, as the competitive microbe was able to inhibit their multiplication [36], therefore, also not detectable in the conventional bacteriological method.

Besides, in the study, samples obtained from domestic pigeons, consisted of intestinal contents, and the samples of vultures were cloacal swabs. In a comparative study of biological samples as described by TEMELLI, et al [19], applying rPCR analysis and bacterial culture in the detection of Salmonella species, the use of intestinal content generates more reliable results comparison to cloacal swabs, like the ones used for the analysis of vulture samples. The freshness of the fecal sample at the time of analysis and the level of humidity can result in false negative detection. Furthermore, large quantities of DNazes enzymes, proteases, and polysaccharides are present in the feces, which can be PCR inhibitory factors [18]. However, the pre-enrichment, as performed in the present study, acts as an inhibitor of these agents, reducing their negative effects in the reaction [20].

Silva et al. [38] who studied the dietary habits of vultures, observed that there is direct relationship between the dissemination of pathogenic agents and the environmental health, and that this bird can 
even be considered to be a bioindicator of environmental health. Nevertheless, more intensive studies with this avian species are needed as to confirm its role in the epidemiology of salmonellosis.

An populous density of synanthropic animals can lead to an increase of Salmonella infected poultry [38]. Carrier,-host-animals are of great importance as a source of infection, as they can liberate intermittently bacteria through excrements for months, or even years [39], leading to the contamination of the environment that they come in contact with. Due to the difficulties in controlling pathogens in poultry production, adequate sanitary methods, within the facilities, have increasingly become the target for more studies on that subject, and given the importance of such environment to maintain the pathogens [40].

\section{Conclusions}

It can be confirmed that Salmonella enterica, serotype Schwarzengrund, Enteritidis and Typhimurium are present in the microbiota of domestic pigeons, in the metropolitan region of Goiânia. Salmonella species was detected in black-headed vultures, in the metropolitan region of Goiânia.

\section{References}

1. Brasil (2012) Ministério da Agricultura e do Abastecimento. Departamento de Defesa Animal. Coordenação de Vigilância e Programas Sanitários. Programa Nacional de Sanidade Avícola. Portaria Ministerial n 193, de 19 de setembro de 1994. Institui o Programa Nacional de Sanidade Avícola (PNSA) no âmbito da DAS e cria o comitê consultivo do Programa de Sanidade Avícola. Diário Oficial da União.

2. Luttrell P, Fischer JR (2007) Mycoplasmosis. In: Thomas NJ, Hunter DB, Atkinson CT (eds.) Infectious Disease of Wild Birds. Blackwel publishing, Iowa.

3. Nunes VFP (2003) Pombos urbanos: o desafio de controle. Revista do instituto Biológico, São Paulo 65: 89-92.

4. Sick H (2001) Ornitologia Brasileira. Nova Fronteira, Rio de Janeiro, Brazil..

5. Del Hoyo J, Elliott A, Christie DA (2003) Handbook of the Birds of the World. Lynx Edicions, Barcelona.

6. Santiago R G (2006) Urubu-de-cabeça-preta (Coragyps atratus) Guia Interativo de Aves Urbanas, 06 dez.

7. Yorio P, Giaccardi M (2002) Urban and fishery waste tips as food sources for birds in northern coastal Patagonia, Argentina. Ornitologia Neotropical 13: 283-292.

8. Brasil (2012) Ministério da Agricultura, Pecuária e Abastecimento. Aves, 2012. Disponível em.

9. Doust P, Prescott JF (2007) Salmonellosis, in: Infections Diseases of Wild Bids. Blackwell publishing, Iowa.

10. Lopes LFL (2008) Salmonella sp. Em répteis e aves silvestres no estado de São Paulo: Freqüência de isolamento, caracterização dos isolados e as conseqüências para o manejo em cativeiro e reintrodução. Tese (Doutorado em Patologia Experimental e Comparada)-Faculdade de Medicina Veterinária e Zootecnia, Universidade de São Paulo.

11. Carvalho VM (2006) Colibacilose e salmonelose. In: Cubas ZS, Silva JCR, Catão-Dias JL (eds.), Tratado de Animais Selvagens. Medicina Veterinária. São Paulo,Roca.

12. Hernandez-Divers SM, Villegas P, Prieto F, Unda JC, Stedman N, et al. (2006) A survey of selected avian pathogens of backyard poultry in Northwestern Ecuador. Journal of Avian Medicine and Surgery 20: 147-158.

13. Pennycott TW, Park A, Mather HA (2006) Isolation of different serovars of Salmonella enterica from wild birds in Great Britain between 1995 and 2003. Vet Rec 158: 817-820.
14. Georgia Poultry Laboratory (1997) Monitoring and detection of Salmonella in poultry and poultry environments. Oakwood.

15. dos Santos LR, do Nascimento VP, de Oliveira SD, Flores ML, Pontes AP, et al. (2001) Polymerase chain reaction (PCR) for the detection of Salmonella in artificially inoculated chicken meat. Rev Inst Med Trop Sao Paulo 43: 247-250.

16. Calvó L, Martinez-Planells A, Pardos-Bosh J, Garcia-Gil LJ (2008) A New Real-Time PCR Assay for the Specific Detection of Salmonella spp. Targeting the bipA Gene. Food Analytical Methods 1: 236-242.

17. Dilmaghani M, Ahmadi M, Zahraei-Salehi T, Talebi T (2007) Detection of Salmonella enterica Serovar Typhimurium from avians using Multiplex-PCR. Veterinary Research Forum 2: 157-165.

18. Malorny B, Paccassoni E, Fach P, Bunge C, Martin A, et al. (2004) Diagnostic real-time PCR for detection of Salmonella in food. Appl Environ Microbiol 70: 7046-7052.

19. Temelli S, Kahya S, Eyigor A, Carli KT (2010) Incidence of Salmonella Enteritidis in Chicken layer flocks in Turkey: Results by Real-time polymerase chain reaction and international organization culture methods. Poultry Science 89: 1406-1410.

20. Sommer D, Enderlein D, Antakli A, Schönenbrücher H, Slaghuis J, et al. (2012) Salmonella detection in poultry samples. Comparison of two commercial real-time PCR systems with culture methods for the detection of Salmonella spp. in environmental and fecal samples of poultry. Tierarztl Prax Ausg G Grosstiere Nutztiere 40: 383-389.

21. Eriksson E, Aspan A (2007) Comparison of culture, ELISA and PCR techniques for Salmonella detection in faecal samples for cattle, pig and poultry. BMC Vet Res 3: 21.

22. Andrade RB, Gemelli LP, Dall Onder LP, Cristina K, Brito T, et al. (2010) Metodos diagnostico para os patógenos alimentares Campylobacter sp., Salmonella sp.e Listeria monocytogenes. Arquivos Instituto Biológico, São Paulo 77.

23. Akbarmehr J (2010) Isolation of Salmonella spp from poultry (ostrich, pigeon, and chicken) and detection of their hilA gene by PCR method. African Journal of Microbiology Research 4: 2678-2681.

24. Khoo CH, Cheah YK, Lee LH, Sim JH, Salleh NA, et al. (2009) Virulotyping of Salmonella enterica subsp. enterica isolated from indigenous vegetables and poultry meat in Malaysia using multiplexPCR. Antonie van Leeuwenhoek 96: 441-457.

25. Chen MH, Wang SW, Hwang WZ, Tsai SJ, Hsih YC, et al. (2010) Contamination of Salmonella Schwarzengrund cells in chicken meat from traditional marketplaces in Taiwan and comparison of their antibiograms with those of the human isolates. Poult Sci 89: 359-365.

26. Aarestrup FM, Hendriksen RS, Lockett J, Gay K, Teates K, et al. (2007) International Spread of Multidrug-resistant Salmonella Schwarzengrund in Food Products. Emerging Infectious Diseases 13: 726-731.

27. Pedersen K, Clark L, Andelt WF, Salman MD (2006) Prevalence of shiga toxin-producing Escherichia coli and Salmonella enteric in rock pigeons captured in fort Collins Colorado. J Wildl Dis 42: 46-55.

28. Marciano JA (2004) Pesquisa de Salmonella spp. Cryptococus neoformans e anticorpos anti toxoplasma gondii em pombos urbanos (Columba livia) no município de Jaboticabal-SP. 65f. Dissertação (Mestrado)-Faculdade de ciências Agrarias e Veterinárias, Universidade Estadual Paulista, Jaboticabal, São Paulo, Brazil.

29. Vucemilo M, Vlahovic K, Dovc A, Muzinic J, Pavlak M, et al. (2003) Prevalence of Campylobacter jejuni, Salmonella typhimurium,and avian Paramyxovirus type 1 (PMV-1) in pigeons from different regions in Croatia. Zeitschrift Fur Jagdwissens 49: 303-313.

30. Pasmans F, Immerseel FV, Hermans K, Heydrickx M, Collard J, et al. (2004) Assesment of virulence of pigeon isolates of Salmonella enteric subsp. Enteric serovar Typhimurium Variant Copenhagen for humans. J Clin Microbiol 42: 2000-2002.

31. Sousa E, Werther K, Berquieri Junior A (2010) Assessment of Newcastle and infectious bronchitis pathogens and Salmonella spp. In wild birds captured near poultry facilities. Arq Bras Med Vet e Zootec 62: 219-223.

32. Tizard I (2004) Salmonellosis in wild birds. Seminars in avian and exotic pet medicine 13: 50-66. 
Citation: Hidasi HW, Andrade MA, Linhares GFC, de Sá Jayme V, Delfino DAA, et al. (2015) Detection of Salmonella enterica in Synanthropic Birds in the Metropolitan Area of Goiania-Go. Clin Microbiol 4: 202. doi:10.4172/2327-5073.1000202

Page 6 of 6

33. Cížek A, Dolejská M, Karpíšková R, Dedicová D, Literák I (2007) Wild black-headed gulls (Larus ridibundus) as an environmental reservoir of Salmonella strains resistant to antimicrobial drugs. European Journal of Wildlife Research 53: 55-60.

34. Lillehaug A, Monceyron Jonassen C, Bergsjø B, Hofshagen M, Tharaldsen J, et al. (2005) Screning of feral Pigeon (Columba livia), Mallard (Anas platyrhynchos) and Grayland Goose (Anser anser) Populations for Campylobacter spp., Salmonella spp., Avian Influenza Virus and Avian Paramyxovirus. Acta Vet Scand 46: 193-202.

35. Ocando DCO, Pirela SER, Ajjam E, Auverty RS (1991) Caracterizacion protéica Del suero Del ave Coragyps atratus (Zamuro de cabeza negra) y algunos estúdios inmunoserologicos. Revista Cientifica FCV de LUZ, Maracaibo 1: 57-70

36. Carvalho LR, Farias LM, Nicoli JR, Silva MCF, Corsino ATSM, et al. (2003) Dominant culturable bacterial microbiota in the digestive tract of the American black vulture (Coragyps atratus Beichstein 1793) and search for antagonistic substances. Brazilian Journal of Microbiology 34: 218-224.

37. Silva MA, Marvulo MFV, Mota RA, Silva JCR (2010) A importância da ordem Ciconiiformes na cadeiaepidemiológica de Salmonellaspp. para a saúdepública e a conservação da diversidade biológica. Pesq Vet Bras 30: 573-580.

38. Lapuz RR, Umali DV, Suzuki T, Shirota K, Katoh H (2012) Comparison of the prevalence of Salmonella infection in layer hens from commercial layer farms with high and low rodent densities. Avian Dis 56: 29-34.

39. Hales RC, Hales MA (2003) Salmonella: Market opportunities for the animal health industry. Animal Pharm Reports, PJB Publications, New York.

40. Refsum T, Vikøren T, Handeland K, Kapperud G, Holstad G (2003) Epidemiologic and pathologic aspects of Salmonella typhimurium infection in passerine birds in Norway. J Wildl Dis 39: 64-72. 